\title{
Askerî Mecmua'ya Göre Çanakkale Cephesinde Türk-Alman İttifakı
}

\author{
Hakan Türkkan*
}

\section{Özet}

Almanya, Birinci Dünya Savaşı sırasında Osmanlı İmparatorluğu'nun en önemli müttefiki olarak ön plana çıkar. Birinci Dünya Savaşı'nda ve özellikle Çanakkale Cephesi'nde görev almış kişilerin Askerî Mecmua'da kaleme aldıkları bazı çalışmalar Türk-Alman ittifakı konusunda önemli ipuçları verir. Bu çalışma Almanya'nın ittifak anlayışını Çanakkale Cephesi'nde yaşananlar açısından ele almaktadır.

Anahtar Kelimeler: Askerî Mecmua, Çanakkale Cephesi, Osmanlı Devleti, Almanya, İttifak.

\section{Turkish-German Alliance in the Gallipoli Campaign According to the Askeri Mecmua (Military Journal)}

\section{Abstract}

Germany was one of the most important allied of the Ottoman Empire in the First World War. Some people who served in the army and especially Gallipoli Campaign during WWI wrote some articles in one of the journals called "Askeri Mecmua" (Military Journal). There are very significant clues related with Turk- German alliance in those works. This research paper focuses on strategical alliance of Germany in terms of Gallipoli Campaign.

Keywords: Askeri Mecmua (Military Journal), Gallipoli Campaign, Ottoman Empire, Germany, Alliance.

\section{Giriş}

Çanakkale Cephesi en kanlı muharebelerin yaşandığı ve Birinci Dünya Savaşı'nın kaderini tayin eden cephelerden biridir. Osmanlı Devleti'nde görev yapmakta olan Alman komutanlar Çanakkale

\footnotetext{
Yrd. Doç. Dr., Karabük Üniversitesi, Edebiyat Fakültesi, Tarih Bölümü, Karabük, hakanturkkan@karabuk.edu.tr. (Makale gönderim tarihi: 25.01.2017, makale kabul tarihi: 30.03.2017).
}

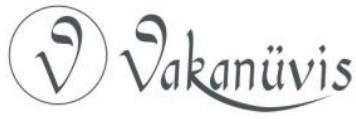


Cephesi'nde çok önemli ve hassas görevlerde bulunmuşlardır. Askerî Mecmua'da ${ }^{1}$ Çanakkale Cephesi ve bu cephede görev yapan Alman komutanlardan da bahseden çeşitli yazılarda ortaya koyulan düşünceler Çanakkale Cephesinde Türk-Alman ilişkileri hakkında fikir vermektedir. Mecmuada farklı tarih aralıklarında yer alan askerî tarih olaylarından, biyografik çalışmalara ve askerlik mesleği ile ilgili teknik meselelere kadar geniş bir yelpaze okuyucuya sunulmuştur². Mecmua'nın Birinci Dünya Savaşı yıllarından sonra yayınlanmış olan sayılarında, Birinci Dünya Savaşını yaşamış ve hatıraları henüz taze olan asker ve komutanların yazıları mevcuttur.

Osmanlı Devleti ile Almanya'nın ilişkileri Birinci Dünya Savaşı'ndan önceye dayanmaktadır. II. Abdülhamid döneminde Almanya ile Osmanlı Devleti arasındaki ilişkilerin özel bir yere sahip olduğunu söylemek mümkündür. Ekonomik ve siyasi konjonktür iki devletin ilişkilerinin artmasına zemin hazırlamıştır ${ }^{3}$. Almanların siyasî ve ekonomik ihtirasları, onların doğuya yönelmelerine sebep olmuştur. Bu bağlamda Almanların, doğudaki hedeflerine ulaşmak için Osmanlı İmparatorluğunu kullanma yolunu seçtikleri görülür. Pek çok seyyah, alim, misyoner, gazeteci ve elçi ile propagandalara girişerek Türklerin güvenini kazanmaya çalışmışlardır. Osmanlı Devleti'nde XIX. yüzyıl sonlarında Almanlara duyulan yakınlıkta, Almanların göstermiş olduğu

1 Askerî Mecmua 1863 yılında "Ceride-i Askerîye" adıyla yayın hayatına başlamıştır. 1878 yılında adı "Mecmua-i Fünûn-ı Askeriye", 1882 yılında "Mecmua-i Askerîye" olarak değiştirilmiştir. Dergi Birinci Dünya Savaşı yıllarında yayın hayatına devam edememiş ancak 1 Mart 1919 tarihinden itibaren "Mecmua-i Askeriye" olarak yeniden yayınlanmaya başlamıştır. 60. Sayıdan yani 1926 Mart ayından itibaren ismi "Askerî Mecmua" olarak değiştirilmiştir. Mart 1948 tarihli 145. Sayısından itibaren ise "Ordu Dergisi” adını almıştır. Bu konuda geniş bilgi için bk. Hamit Pehlivanlı, Genelkurmay Askerî Tarih ve Stratejik Etüt Başkanlığı Süreli Yayınları Makaleler Dizini I, Genel Kurmay Başkanlığı Askerî Tarih ve Stratejik Etüt Başkanlığı Yay. Ankara, 1992, s. XIII.

2 Askerî Mecmua hakkında ayrıntılı bilgi için Bk. Hakan Türkkan, Askerî Mecmua'da Birinci Dünya Savaşı Türk Cepheleri (1-145. Sayılar), Yayınlanmamış Yüksek Lisans Tezi, Kırıkkale, 2007, s. 70.

3 ilber Ortaylı, Ikinci Abdülhamit Döneminde Osmanlı Devleti'nde Alman Nüfuzu, Ankara Üniversitesi Basımevi, Ankara, 1981, s. III-IV.

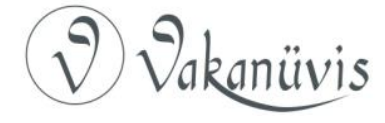


ekonomik ve siyasi gelişmelerle, askerî teknoloji ve disiplin anlayışına duyulan sempatinin de etkisinin olduğu söylenebilir ${ }^{4}$. Osmanlı Devleti özellikle askeri teknoloji ve talim terbiye hususunda Alman personelden yararlanmaya çalışmış bu nedenle Alman subay ve askerî uzmanların esnek prosedürler ve yüksek ücretlerle Osmanlı Ordusunda görevlendirilmesi söz konusu olmuştur. Örneğin 1883 yılının başlarında İstanbul'a gelen Binbaşı Colmar von der Goltz Osmanlı Devleti'nde askeri eğitim öğretim konularında görevlendirilmiş ve 1885 yılında Osmanlı Devleti'ndeki Alman heyetinin başı olmuştur. Gerek Goltz'un faaliyetleri gerekse daha sonraki dönemlerde Alman heyetlerinin faaliyetleri Osmanlı Devleti'nde Almanlara duyulan yakınlığın artmasına katkıda bulunmuştur ${ }^{5}$.

\section{Birinci Dünya Savaşı'nda Türk-Alman İttifakı}

Türklerin Almanlarla birlikte savaşa katılmalarına hem Almanya açısından hem de Osmanlı Devleti açısından çeşitli sebepler etki etmiştir ${ }^{6}$. Birinci Dünya Savaşı döneminde Almanya açısından Türkiye'nin ekonomik ve askerî önemi daha da artacaktır. Çünkü Almanya, bir yandan Türkiye'nin hammaddelerinden istifade etmek, diğer yandan da Süveyş, Mısır ve Kuzey Afrika'ya ulaşmak amacını gütmüştür. Osmanlı Devleti'nin kendisine sığınacak liman aradığı bir dönemde Almanya'nın kendisine yük olacak bir devletle ittifakı kabul etmesi, kendisi aleyhinde yapılan hazırlıklardan ürkerek durumunu güçlendirmeye çalışması şeklinde değerlendirilebilir ${ }^{7}$.

Birinci Dünya Savaşı sırasında Türk-Alman ilişkilerinin hükümetler arası ve askerî komuta makamları arasındaki ilişkiler olmak üzere iki şekilde geliştiği görülür. Askerî Mecmua'da kaleme alınmış olan çalışmalarda Türk-Alman ilişkilerinin daha çok askerî ilişkiler açısından

4 M. Laşer , "Büyük Harp Esnasında Alman ve Türk Kumandanlıkları”, Çev. İbrahim, Askerî Mecmua, Sayı 59, İstanbul, 1 Aralık 1925, s. 48-49.

5 Faruk Yılmaz, Imparatorluk Döneminde Türk-Alman ilişkileri (Goltz Paşa'nın Hatıraları), Berikan Yay. Ankara, 2004, s.9-10.

${ }^{6}$ A. M. Zayonçkovskiy, "Büyük harp (1914-1918) Kafkas Cephesi”, Çev. Latif, Askerî Mecmua, Sayı 97, İstanbul, Haziran 1935, s. 480-486

7 Türk Alman İttifakı konusunda Cemal Paşa'nın Hatıralarında birinci ağızdan verdiği detaylı bilgi için Bk. Cemal Paşa, Hatıralar, Haz. Alpay Kabacalı, Türkiye İs Bankası Yay., İstanbul, 2008, s. 130-140.

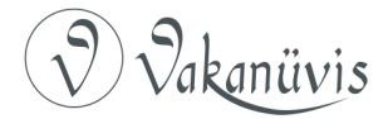


incelendiğini görmekteyiz. Osmanlı Devleti henüz savaşın başı sayılabilecek bir dönemde, Alman generallere bazı önemli görevler vermiştir. Amiral Souchon'a Türk Donanma Komutanlığı ve General Weber'e Çanakkale Müstahkem Mevkii Genel Müfettişliği görevi verilmiş olması Osmanlı Devleti'nin Almanlara duyduğu güvenin bir göstergesi olup Türk-Alman ittifakının geldiği noktayı göstermesi açısından dikkate değerdir ${ }^{8}$.

Türkiye'de görev yapan Alman General Liman von Sanders'in henüz 1913 yılında kurmuş olduğu askerî heyet, Birinci Dünya Savaşı'nda Türk-Alman münasebetlerinin yönünü tayin etmiştir. Binbaşı M. Laşer tarafından kaleme alınmış olan "Büyük Harp Esnasında Türk ve Alman Kumandanlıkları” isimli çalışma, bu heyetin Osmanlı Devleti üzerindeki etkileri hakkında bilgi vermektedir. Buna göre Liman von Sanders'in heyeti, Alman Imparatoru'na bağlı ve özerk bir yapıda görev yapmıştır. Heyetin mevcudu önceleri 42 iken daha sonra bu sayı 70'e ulaşmıştır. Bu heyete bağlı olarak görev yapmakta olan Alman subayları Osmanlı Devleti'nde görev yaparken Almanya'daki rütbelerinin bir derece üstünde bulunmuşlardır. Söz konusu heyetin başkanı olan Liman von Sanders, Ordu Genel Müfettişi ve I. Ordu Komutanlığı görevini üstlenmiştir. Bunun yanı sıra Alman heyeti, Osmanlı Devleti içerisinde son derece önemli yetki ve imtiyazlara da sahip olmuştur. Örneğin Osmanlı Devleti askerî makamları, savaş plânları, orduların küçültülmesi, önemli terfiler gibi konularda Liman von Sanders'e danışmak zorundaydılar. Ayrıca heyetin mensupları, protokolde vekillerden sonra ve sefirler ile aynı seviyede idi. Liman von Sanders, sahip olduğu bu imtiyaz ve yetkilerle 1914 yılının ilk yarısında Osmanlı Devleti içinde bir dizi siyasî ve askerî faaliyetlerde bulunmuştur. Alman heyetinin Osmanlı Devleti'ndeki durumunu tespit eden yürürlükteki anlaşmalara ek olarak Liman von Sanders, Enver Paşa ile de bir mukavele yapmıştır. Bu mukavele ile Osmanlı Ordusunun fiili sevk ve idaresi Almanlara verilmiştir. Alman heyetine mensup subaylar, şube ve kurmay başkanlıklarında, tümen, alay veya talimgâh komutanlıklarında görev yapmıştır. Rütbesi daha küçük olan Alman

\footnotetext{
${ }^{8}$ Zayonçkovskiy, a.g.m., s. 447.

${ }^{9}$ Laşer, a.g.m., s. 50-51.
}

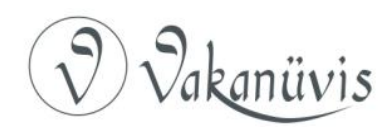


subayları ise Türk birliklerinin takviye edilmesinde kullanılmıştır. Türkler bu suretle kendi hareket serbestîlerinin bir bölümünü, bazı takviye ve harp malzemeleri karşııı̆ında Alman askerî heyetine bırakma yoluna gitmişlerdir. Bu durum, Osmanlı Devleti ordularının fiili sevk ve idaresindeki Alman tesirini de güçlendirmiş ve Alman askerî heyetinin Osmanlı askerî makamlarına olan etkisi önemli boyutlara ulaşmıştır.

Osmanlı Devleti'nin, harekât planlarının bile Almanlarla birlikte yapılmış olduğu görülür. Bu bakımdan harekât planlarının çoğunlukla Almanya'nın yükünü hafifletmek amacına yönelik olduğu görülmektedir. Dolayısıyla Almanlar, Osmanlı ordularının İtilaf Kuvvetlerine taarruz etmesi ile birlikte itilaf Ordularının bir kısmının Batı Cephesinden alıkonulmasını ve Boğazların kapatılması ile Çarlık Rusya'sının yalnız bırakılmasını ümit etmişlerdir ${ }^{10}$.

Birinci Dünya Savaşı'nda Türk ve Alman askerî makamlarının ilişkileri, savaşın şartlarına göre gelişmeler göstermiştir. 1914 yılında Almanların Osmanlı Devleti'ndeki itibarı yüksekti. Bu durum zafere olan inancı da arttırmış ve Türk Başkomutanlık Vekâleti bu dönemde Almanya'nın telkin ve arzularına uymakta bir sakınca görmemiştir. Dolayısıyla ilk dönemlerde Alman subaylarının Türk askeriyle olan teşriki mesaisinde çok ciddi sorunlar yaşanmadığı söylenebilir. Ancak bu dönemde gelişmekte olan Türk milliyetçiliği, savaş sırasında karşılaşılan başarısızlık ve felaketlerin etkisiyle iki ülke askerî makamları arasındaki ilişkilerin bozulması, uzun süre devam eden muharebelerin ortaya çıkardığı sorunlar, Birinci Dünya Savaşı'nda TürkAlman münasebetlerinin yönünü belirlemiştir ${ }^{11}$.

\section{Çanakkale Cephesi'nde Türk-Alman İttifakı}

Savaş şartlarının ağırlaşması ve Alman subaylarının despotça tavırları iki müttefikin cephedeki ilişkilerine olumsuz yönde yansır. Çanakkale Cephesi bu olumsuzluğun ciddi biçimde hissedildiği bir alandır $^{12}$. Çanakkale'de büyük bir cephenin açılması ve bu cephenin

10 Şemsi Zobu, "Çanakkale Nasıl Müdafaa Edildi?”, Askerî Mecmua, C. VI, Sayı 98, İstanbul, 1 Eylül 1935, s.763.

${ }^{11}$ Laşer, a.g.m., s. 60.

12 Palmer, a.g.e., s. 352.

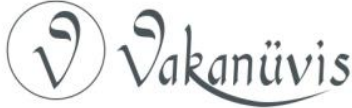


savaşı yönlendirecek derecede önemli hale gelmesi bir rastlantı değildir. Çanakkale ve Karadeniz Boğazları bölgesi Osmanlı Devleti'nin tarafsızlığını koruması durumunda bile I. Dünya Savaşı boyunca İtilaf Devletleri tarafından mutlaka başvurulacak bir bölge durumunda idi. Rusya ile bağlantı kurup Rus Ordusunun imdadına yetişmek mecburiyeti de İngiltere ve Fransa tarafından Boğazlara yönelik bir teşebbüs için yeter bir sebep idi. Osmanlı Devleti ise böyle bir teşebbüste Boğazlardan geçişe izin vererek düşmanı olan Rusya'ya kendi eli ile yardım etmiş olacaktı. Askerî Mecmua'da bu hususta görüş bildiren Mehmet Nihat'a göre, Boğazlardan geçişe izin vermemek Osmanlı Devleti için Çanakkale'de yine mutlak bir savaş anlamına gelecekti $^{13}$. Nihayet Türk Ordusu, Çanakkale'de kendisinden silah ve mühimmat bakımından çok daha donanımlı ve üstün düşman ordusuna karşı mücadele etmek durumunda kalmış ve bu savaş hem karada hem de denizde 9 ay kadar devam etmiştir ${ }^{14}$.

Türklerin ve Almanların Çanakkale Cephesindeki münasebetlerinden söz ederken öncelikle İtilaf kuvvetlerinin durumları hakkında bilgi vermek yerinde olacaktır. Çanakkale cephesinde meydana gelen muharebelerde İngiliz savaş muhabiri olarak bulunan Elis Bartlet'in savaş hakkında ülkesine gönderdiği raporlarda samimi itiraflarda bulunmaktadır. Çanakkale'ye Daily Telegraph"ın muhabiri olarak gelen ünlü savaş muhabirinin raporları ilk dönemlerde sansürlü olarak parça parça yayınlamıştır. $O$, hadiseleri bir gazeteci gözüyle izlemiş ve şahit olduğu olayları bizzat kaleme almıştır. Bartlet'in raporlarında yer alan bilgiler değerlendirildiğinde İtilaf Devletlerinin, çıkarma harekâtının ilk günlerinde pek de iç açıcı bir durumda olmadıkları anlaşıır. Bartlet; harp gemilerinin desteği altındaki nakliye gemilerinin Mondros Limanı'ndan ayrılmaları anındaki durumu dünyada eşi görülmemiş bir hal olarak ifade eder. Muhabir, buradaki manzaranın "doldurulmuş sardalye kutularının istifi" gibi olduğunu belirtmektedir. Anzaçların karaya çıkartılmasını "Londra" isimli savaş gemisinden izlemiş ve bir müddet sonra kendisi de karaya çıkmıştır.

13 Mehmet Nihat, "Büyük Harpte Çanakkale Seferi (1914-1918)", Askerî Mecmua, Sayı 70, İstanbul, Eylül 1928, s.5.

${ }^{14}$ İsmet Görgülü, On Yılık Harbin Kadrosu 1912-1922, Türk Tarih Kurumu Yay., Ankara, 1993, s. 54.

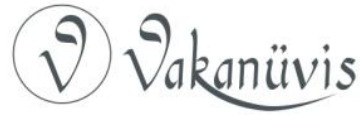


Anzaçların karaya çıkışları ile ilgili olarak; Avustralya askerlerinin Türklerin karşı taarruzlarından yıldıklarını ve tek kurtuluş çaresini ise yeniden gemilerine binmeye çalışmakta bulduklarını söylemektedir. Fakat Başkomutanlık, çıkarma harekâtında kararlıdır. Müteakip teşebbüsler Helles Burnu'nda gerçekleştirilecek olan çıkarma harekâtı ile birleştirilerek devam ettirilmiştir. Muhabir, bir sonraki büyük harekâtın, İngiliz ve Fransızların Kirte ve Hacıbaba'da Türk mevzilerine karşı düzenledikleri taarruz olduğunu ve üç gün boyunca tekrarlanan saldırılarla bölgenin "mezbahaneye" dönmesine rağmen İtilaf Kuvvetlerinin başarı elde edemediklerini belirtmektedir ${ }^{15}$.

Bu şartlar altında bulunan Çanakkale Cephesi, Türk ve Alman askerinin fiili olarak birlikte görev yaptığı fakat Türk askerinin adeta Alman komutanlara teslim edildiği cephe durumunu arz etmekteydi. Elbette Osmanlı Devleti'nin Alman askerî tecrübesine duyduğu güven bunda etkili olmuştur. Almanların Çanakkale Cephesi'nde savaş tekniği ve cesaret noktasında ortaya koydukları performans ve savaşın sevk ve idaresinde üstlendikleri büyük sorumluluğu yerine getirmedeki başarıları veya başarısızlıkları Askerî Mecmua'da tartışma konusu olmuştur. Mecmua'da yayınlanmış olan çalışmalarda Çanakkale Cephesinde Türk-Alman münasebetleri hakkında yer alan bilgiler çoğunlukla yazarların yorumlarına ve yaşamış oldukları bir takım olaylara dayanmaktadır ${ }^{16}$.

Çanakkale Cephesinde muharebelerin bütün şiddeti ile devam ettiği sırada Almanlar Lehistan'daki Rus Orduları ile mücadele halinde idiler. $\mathrm{Bu}$ nedenle Çanakkale Boğazı'nın İngiliz-Fransız Birleşik Filosu tarafından açılması ve Rusya'nın ihtiyaç duyduğu yardıma kavuşması Almanlar açısından tehlikeli bir durum ortaya çıkarabilirdi. Bu endişe, Almanları Çanakkale Cephesindeki muharebelere fiili olarak destek olmaya teşvik etmiştir. İtilaf Devletleri tarafından Çanakkale'ye karşı girişilen harekât Türklere ve Almanlara daha sıkı bir ittifak içerisinde bulunmaları gerektiğini düşündürtmüştür ${ }^{17}$. Çanakkale Cephesinin en önemli kuvvetlerinden biri olan V. Ordu Komutanlığı'na Alman General

15 Mosorof, "Çanakkale”, Çev..A. Şevket, Askerî Mecmua, Sayı 71, İstanbul, 1 Kasım 1928, s. 15-16.

16 Türkkan, a.g.t., s. 114-126.

${ }^{17}$ Laşer, a.g.m., s. 59.

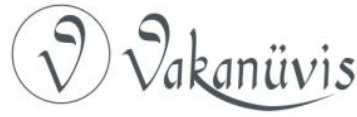


Liman von Sanders getirilmiş ve General Sanders Türk kuvvetlerine kayıtsız şartsız komuta etmiştir ${ }^{18}$. Onun Çanakkale Cephesindeki faaliyetleri Askerî Mecmua'da ele alınan hususlar arasındadır. Liman von Sanders'in Gelibolu'ya geldiği tarih olan 26 Mart 1915'te bölgede bulunan 5 adet piyade tümeni, Albay Cevad (Çobanlı) komutasında görev yapmaktaydı. Alman General, Çanakkale Cephesindeki bütün savunma hazırlıklarını çoğunlukla kendi düşüncesine göre yapar. Fakat Şemsi Zobu, Alman generalin Çanakkale Cephesi ile ilgili savunma planlarının bir takım hataları içerdiğini düşünmektedir. Daha da önemlisi yazar, Alman generalin, İtilaf Kuvvetlerinin amaçlarına ulaşmalarını engelleyecek şekilde bir savunma plânı yapmadığı görüşünü taşımaktadır.

Çanakkale Cephesinde Alman generalle Türk komutanlar arasında yaşanan bazı fikir ayrılıklarının da Askerî Mecmua'ya yansıdı̆̆ı görülmektedir. Örneğin, Cephede alınacak savunma düzeni konusunda bir fikir ayrılığı yaşanmıştır. Bu ayrılığın konusu ise Çanakkale'ye çıkarma yapan İtilaf Kuvvetlerine sahile çıkmadan mı; yoksa sahile çıktıktan sonra mı Türk taarruzunun başlatılması meselesidir. Alman general Liman von Sanders bu konuda, kıyılara zayıf gözetleme kuvvetleri koymayı ve düşmanın sahile çıkmasının beklenerek toplu bir taarruzla denize dökülmesini plânlamıştır. Şemsi Zobu, savunma alanının dar olmasından ve İtilaf Kuvvetlerinin çıkarmayı topçu ateşi ile destekleyeceğinden dolayı böyle bir savunmanın başarısız olacağını ifade etmiştir. Ancak Alman generalin düşüncesinden vazgeçmeyerek plânını uyguladığı görülmektedir. Muharebelerin seyri Türk komutanları haklı çıkarmıştır ${ }^{19}$.

Liman von Sanders'in Çanakkale Cephesinde bulunduğu süre içerisinde değişik zamanlarda yaptığı bazı hataları kendisinin de kabul ettiği belirtilmiştir. Örneğin 5 Mayıs 1915 tarihinde Arıburnu Cephesinde, II. Tümenin bir gecede 9.000 zayiat vermesine neden olduğu görülmektedir. Şemsi Zobu'ya göre, Alman komutanların yapmış oldukları en önemli hata sevk ve idarede sabit fikre sahip olmaları ve kendilerini belli bir noktaya kaptırarak düşmanın yapması muhtemel hareketlerin yeterince hesaplanmamasıdır. Bu tutum

\footnotetext{
${ }^{18}$ Laşer, a.g.m., s. 51.

${ }^{19}$ Zobu, a.g.m., s. 764-769.
}

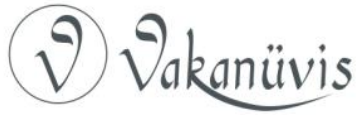


düşmanın vurucu gücünün tespitini zorlaştırmış ve orduların yanlış yönlendirilmesi sonucunu doğurmuştur. Çanakkale'de V. Ordu Komutanı olarak görev yapmakta olan Liman von Sanders'in, düşmanın asıl kuvvetleri ile Saros ve Beşike'den çıkarma yapacağı düşüncesine saplanıp kalması yukarıda sözünü ettiğimiz savaşın sevk ve idaresinde sabit fikre örnek olarak gösterilebilir. İtilaf kuvvetlerinin farklı bir noktadan asıl kuvvetleri ile çıkarma yapmakta olduklarına dair raporlar alındığı sırada dahi Liman Paşa'nın Bolayır sırtlarında büyük miktarlarda askerî gücü bekletmesinin önemli bir hata olduğu ortaya koyulmaktadır. Alman General'in Çanakkale cephesinde yapmış olduğu başka bir hata olarak Askerî Mecmua'da üzerinde durulan diğer bir husus ise, tüm kuvvetleri asıl çıkarma bölgesi olan güneye kaydırmak yerine yalnızca V. ve VII. Tümenlerden bazı kuvvetleri buraya göndermesi, dolayısıyla kuvvetlerin parçalanmasına neden olmasıdır. Şemsi Zobu bu hatalar konusunda Alman Generalin uyarıları dikkate almaması ve kendi düşüncesinde ısrar etmesi sonucunda Gelibolu Yarımadası'nın adeta "mezbahaneye" döndüğünü söylemiştir ${ }^{20}$. Liman von Sanders'in Çanakkale Cephesi'nde hatalar yaptığına ve bu nedenle Türk askerinin büyük kayıplara uğradığına dair Askerî Mecmua'da ortaya atılan görüşlere karşılık, onun cephedeki savunma tedbirlerini gayet iyi aldığını ve çıkarmanın nereye yapılacağı konusunda isabetli karar verdiğini düşünen kesimler de bulunmaktadır ${ }^{21}$.

Çanakkale Cephesinde bizzat görev yapmış biri olan Yarbay Mehmet Nihat, Askerî Mecmua'da yayınlanmış olan hatıralarında Çanakkale Cephesi'nde yaşananları, Türk ve Alman komuta makamları arasında ortaya çıkan uyumsuzluklar açısından değerlendirmektedir. Yarbay Mehmet Nihat Çalışmasında; Osmanlı Devleti'nin daha önce yaşadığı Balkan Savaşı v.b felaketlerin sebeplerinin tam olarak araştırılıp yazılmadı̆ı̆ı ıelirtir. Herkesin Türk asker ve milletinin mazisindeki kudretini kaybettiği ve ordunun günün gereklerine göre yetişmediği için mağlup olunduğunu söylendiğini ifade eder. Fakat yazar, Balkan Savaşlarının bazı sevk ve idare hataları nedeniyle kaybedildiğinin pek fazla dile getirilmediğini düşünmektedir. Mehmet

${ }^{20}$ Zobu, a.g.m., s. 764, 768.

${ }^{21}$ A. Thomazi, Çanakkale Deniz Savaşı, Genelkurmay Basımevi, Ankara, 1997, s. 68 .

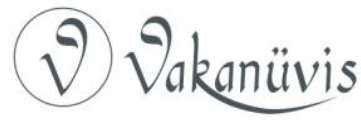


Nihat, Türklerin kendilerine fena dediklerini, dolayısıyla Almanların çok fena demelerine şaşılmaması gerektiğini belirtmiştir. Nitekim XV. Kolordu Kurmay Başkanı Yarbay Tofaniy, Birinci Şube Müdürü olan yazarımız Mehmet Nihat'a "Monşer, biliyorsun ya sizin asker İngiliz ve Fransız ordusuna karşı koyamaz. Fakat ne çare ki elimizden geleni yapacağız" demiştir. Yarbay Tofaniy'nin bu düşüncesini, Çanakkale'de güney grubunda her gün yeni bir Türk başarısı ortaya çıkarken bile değiştirmediği ve yazarımıza her defasında; "Bu defa da dayandılar ama gelecek sefere paydostur", demekte ısrar ettiği görülmektedir. Gelişmeler, Yarbay Tofaniy'i haksız çıkarmıştır. Çünkü Almanların, ilk çıkarma günlerinde güvenilir tek kuvvet olarak gördükleri Alman Deniz askerlerinden oluşan bir makineli tüfek bölüğü cepheye geldikten birkaç gün sonra karşılaştıkları ilk taarruzda tüfeklerini bırakarak kaçmışlardır. Alman askerlerinin bırakıp kaçtıkları bu bölgede Türk askerînden oluşan yeni bir makineli tüfek bölüğü oluşturulmuştur. Yazar bu nedenle, "Almanlar bizim toprağımızda bizim uğrumuzda ölmek istememişlerdi" diyerek, Almanlar hakkındaki düşüncelerini ortaya koymuştur ${ }^{22}$. Yukarıda anlatılanlar Alman komutanlarının bir müttefik olarak Türklere bakış açısını ortaya koyması açısından dikkat çekicidir.

Cephede silahlarını bırakarak kaçan Osmanlı müttefiki Alman askerlerine karşılık Türk askerinin Çanakkale Cephesi'nde gösterdiği fedakarlık cephede bizzat bulunmuş olanlar tarafından gözlemlenmiştir. İngiliz donanmasının Seddülbahir'e açtığı ateş ile siperler dümdüz olurken bile yaralı olarak kurtarılabilen askerlerin, gördükleri talim, terbiye ve vatanperverlik duyguları ile hareket ettikleri ve yaralandıklarına üzülerek iyileştikten sonra yeniden görev yerlerine dönmek arzusunu dile getirdikleri görülür ${ }^{23}$.

Yine Mehmet Nihat, Alman generallerin tutumları ile ilgili olarak da bazı bilgiler vermiştir. Bu bilgiler Türk - Alman komuta makamları arasındaki anlaşmazlığı ortaya koyması açısından önemlidir. Yazar; XV. Kolordu Komutanı General Weber ve Kurmay Başkanı Tofaniy'nin 26

\footnotetext{
${ }^{22}$ Nihat, a.g.m., s. 44-45, 70-73.

23 Binbaşı Mahmut, "Seddülbahirde ilk ìhraca Karşı Koyan Tabur Kumandanının Notları", Askerî Mecmua, İstanbul, Eylül 1933, Sayı 90, s. 307-322.
}

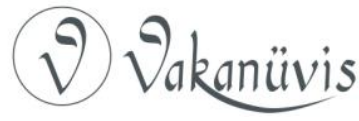


Nisan 1915 sabahı Rumeli tarafında gerçekleşen harekâtı bir gösteri harekâtı olarak gördüklerini ve esas çıkarmanın Beşike'den olacağında ısrar ettiklerini belirtir. Ayrıca 25 Nisandan itibaren Ordu Komutanı ile haberleşmenin kesildiğini ve ordudan herhangi bir emir alınamadığını, 26-27 Nisan günlerinde ise Rumeli'de buhranlı muharebeler devam ederken Anadolu tarafında boşta kalan XV. Kolordunun büyük kısmının bir an önce asıl çıkarma bölgesine sevk edilmesi gerektiği belirtilmiştir. Mehmet Nihat, III. Kolordu Kumandanlığı'nın XV. Kolordudan kuvvet istemesine rağmen, General Weber'in Ordu Komutanının emri olmaksızın kuvvet vermeye yanaşmadığını söyler. Bu yüzden, III. Kolordu Kurmay Başkanı Fahreddin ile Çanakkale Müstahkem Mevkii Şube Müdürü olan yazarımız, bu sorunu çözme kararı almışlardır. Yaptıkları plâna göre Fahreddin, gerektiği zaman kuvvet isteyecekti. Haberleşme şebekesinin kötü olması nedeniyle bu talebe Selahaddin Adil aracılık edecekti. Şayet General Weber razı olmazsa yazarımız Mehmet Nihat, Almanların Türkçe bilmemesinden yararlanarak bir telefonla Ordu emri uyduracak ve Weber'e Ordu Komutanı'nın emridir diye gösterecekti. Yazar, bunun Gerçekten böyle yapıldığını ve bu sayede 26-27 Nisandan itibaren XV. Kolordunun bir kısım kuvvetinın asıl çıkarma sahasına sevk edilebildiğini ifade etmiştir.

Yarbay Mehmet Nihat'ın Çanakkale Cephesinde, General Weber ile olan Illişkisi yukarıda anlatılanlar ile sınırlı değildir. 13 Haziran tarihinde gerçekleştiğini ifade ettiği hadise, Türk ve Alman Komutanlıkları arasında yaşanmakta olan yetki karmaşasını da ortaya koyar. İtilaf kuvvetlerinin 13 Haziran'da başlattığı bombardıman 15 Haziran'da şiddetli bir taarruzla sonuçlanmıştır. İngilizlerin bu taarruz sonucunda denizle Zığındere arasından 2 ila $2.5 \mathrm{~km}$. kadar içeriye girmesi, tehlikeli bir durum ortaya çıkarmıştır. Bu sırada General Weber Güney grubu Komutanı olarak görev yapmaktadır. Bu hadise ortaya çıkıncaya kadar sükunet ve itidalini korumakla birlikte bu hadiseden sonra ani olarak çekilmeye karar vermiştir. Grup I. Şube Müdürü olan yazarımız Mehmet Nihat'a artık başka çare kalmadığını söyleyerek Alçıtepe önündeki son savunma hattına çekilmeye yönelik emri yazmasını söylemiştir. Mehmet Nihat General Weber'i bu kararından vazgeçirmeye çalışmıştır. Fakat başarılı olamamıştır. Bunun üzerine hemen Ordu Kurmay Başkanı olan Diyarbakırlı Kazım Inanç'a haber vermiştir. Kazım İnanç, "ben şimdi geliyorum. Suret-i katide muhalefet

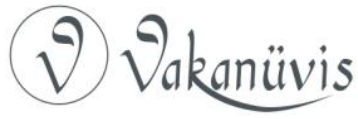


et ve orada yegane hakim unsurun Türk zabiti olduğunu unutma" emrini vermiştir. Bu emirden de anlaşılacağı üzere General Weber'in geri çekilme kararı Türk komuta makamı tarafından kesinlikle tasvip edilmemiştir. Kazım İnanç'ın, Mehmet Nihat'a vermiş olduğu emir ise Türk askerînin bölgede yetkiyi ele almasını sağlamaya yöneliktir. Çanakkale Cephesi'nde yaşanan bu uyuşmazlık, Liman von Sanders'in, General Weber'i görevden alıp yerine II. Ordu Komutanı Vehip Paşa'yı getirmesi ile çözülebilmiştir ${ }^{24}$.

\section{Sonuç}

Almanların Birinci Dünya Savaşı́nın ilk safhalarında Osmanlı Devleti ile bir ittifak niyetinde olmamalarına rağmen savaşın gerektirdiği şartlar nedeniyle Osmanlı Devleti ile ittifak yapmaları maddi çıkar ve stratejik zorunluluklar gereği olmuştur. Eğer, Almanlar Osmanlı coğrafyasının cevherini ve Türk askerinin azmini fark etmeselerdi Osmanlı Devleti'nin ittifak teklifini kabul etmekte güçlük çekebilirlerdi ${ }^{25}$. Alman komutanların Çanakkale Cephesi'nin savunmasında bilinçli veya bilinçsiz olarak Türk askerini felakete sürükleyecek türde kararlara imza attıkları ve bu tür kararlarını uygulamak hususunda da son derece inatçı olduklarını görmekteyiz. Çanakkale Cephesi'nde yaşanan mücadelelerin kritik dönemlerinde alınan hatalı kararların Türk komutanlar tarafından telafi edilmesi gerekmiştir. Türk askerî yetkililerin tüm uyarılarına rağmen hatalı karar veren ve bu kararlarında ısrar eden ayrıca cepheyi kolayca terk eden Alman asker ve komutanlarının niyetleri sorgulanır hale gelmektedir. Bu bakımdan Almanların Çanakkale Cephesi'nde Türklerin müttefiki olarak gereken hassasiyeti ve başarıyı gösteremedikleri veya göstermedikleri anlaşılmaktadır. Böylelikle Çanakkale Cephesi'nde kazanılan zaferin Türk asker ve kumandanlarına yani Türk milletine ait olduğu ortaya çıkmaktadır.

\footnotetext{
${ }^{24}$ Nihat, a.g.m., s. 44-45, 70-73.

25 Türk Silahlı Kuvvetleri Tarihi, 1908-1920, C. III, K.6. Genelkurmay Basımevi, Ankara, 1996, s. 64.
}

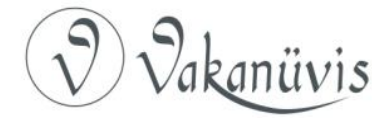




\section{Kaynakça}

Binbaşı Mahmut, "Seddülbahirde illk ihraca Karşı Koyan Tabur Kumandanının Notları", Askerî Mecmua, İstanbul, Eylül 1933, Sayı 90, s. 307-322

Cemal Paşa, Hatıralar, Haz. Alpay Kabacalı, Türkiye iş Bankası Yay., İstanbul, 2008,

Görgülü, İsmet, On Yıllık Harbin Kadrosu 1912-1922, Türk Tarih Kurumu Yay., Ankara, 1993

Laşer, M., "Büyük Harp Esnasında Alman ve Türk Kumandanlıkları", Çev. İbrahim, Askerî Mecmua, Sayı 59, İstanbul, 1 Aralık 1925, s. 48-64.

Mehmet Nihat, "Büyük Harpte Çanakkale Seferi (1914-1918)", Askerî Mecmua, Sayı 70, i̇stanbul, Eylül 1928, s.2-82.

Mosorof, "Çanakkale", Çev..A. Şevket, Askerî Mecmua, Sayı 71, İstanbul, 1 Kasım 1928, s. 15-22.

Ortaylı, İlber, Ikinci Abdülhamit Döneminde Osmanlı Devleti'nde Alman Nüfuzu, Ankara Üniversitesi Basımevi, Ankara, 1981.

Palmer, Alan, Çev.Belkıs Çorakçı Dişbudak, Osmanlı Imparatorluğu Son Üç Yüz Yıl, Sabah Kitapları, İstanbul, 1995.

Pehlivanlı, Hamit, Genelkurmay Askerî Tarih ve Stratejik Etüt Başkanlığı Süreli Yayınları Makaleler Dizini I, Genel Kurmay Başkanlığı Askerî Tarih ve Stratejik Etüt Başkanlığı Yay. Ankara, 1992.

Thomazi, A., Çanakkale Deniz Savaşı, Genelkurmay Basımevi, Ankara, 1997.

Türk Silahlı Kuvvetleri Tarihi, 1908-1920, C. III, K.6. Genelkurmay Basımevi, Ankara, 1996,

TÜRKKAN, Hakan, Askerî Mecmua'da Birinci Dünya Savaşı Türk Cepheleri (1-145. Sayılar), Basılmamış Yüksek Lisans Tezi, Kırıkkale, 2007.

Yılmaz, Faruk, Imparatorluk Döneminde Türk-Alman ilişsileri (Goltz Paşa'nın Hatıraları), Berikan Yay.Ankara, 2004.

Zayonçkovskiy, A.M., "Büyük harp (1914-1918) Kafkas Cephesi”, Çev. Latif, Askerî Mecmua, Sayı 97, İstanbul, Haziran 1935, s. 480-486

Zobu, Şemsi, "Çanakkale Nasıl Müdafaa Edildi", Askerî Mecmua, Sayı 98, İstanbul, Eylül 1935, s. 863-874.

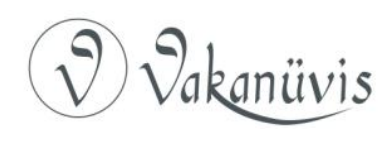

